\title{
En refleksion over den lyriske genres aktuelle status
}

I

Hvis man spørger almindelige læsere om, hvad lyrik er, vil svaret ofte lyde noget i retning af, at det er en litterær kortform på vers, der beskriver et jegs erfaringer, følelser og tanker. Men samtidig med, at det er en meget udbredt forståelse af lyrik, er det også en forståelse, som er udfordret i samtiden; som ikke længere hænger helt så godt sammen med de måder, som genren aktuelt udfolder sig på, hverken herhjemme eller i store dele af udlandet. Det skal selvsagt ikke forstås således, at der ikke længere udgives digtsamlinger med korte tekster, der er opstillet på vers og centreret omkring et jegs monologiske tale. Sådanne mere traditionelle digtformer er langt fra forsvundet. Alligevel er der ingen tvivl om, at vi igennem de seneste år har været vidne til en markant stigning i tekstformer, som unddrager sig disse træk, men alligevel kalder sig for eller opfattes som digte, lyrik eller poesi. Nye poetiske former som f.eks. Christian Yde Frostholms Afrevne ord [netversion] (2004), Morten Søndergaards bogobjekt Ordapotek (2010), Gerd Laugesens tekstfotografier i Lommetørklædesamling (2011), Christina Hagens prosalyriske vredesudbrud i White Girl (2012) og rapprojektet Rødder (2014) har i stigende grad vundet indpas.

I Drømme og dialoger (2009) har Peter Stein Larsen undersøgt, hvordan den danske centrallyriske norm omkring årtusindskiftet er blevet mødt af en fremturende interaktionslyrik, der har et mere stilistisk heterogent, flerstemmigt og dialogisk udtryk, og som dermed står i opposition til den hævdvundne forestilling om digtet som autonomt, stilistisk homogent og med et monologisk, autoritativt udsigelsescentrum. Men som de ovenstående eksempler signalerer, har der foruden ændringerne i den skrevne lyrik også fundet en øget frigørelse sted fra selve det medium, som lyrikken længe har været knyttet til, nemlig bogen. Samtidslyrikken finder man ikke kun på papirsider, men i diverse elektroniske formater, ligesom den manifesterer sig som bogobjekter i udstillingssammenhænge, indtager det offentlige rum, performes og synges. Samtidslyrikken udfolder sig med andre ord på et væld af måder og krydser talrige grænser såvel kunstnerisk som modalt og medialt. 
Denne forgrening kan ses som et vidnesbyrd om lyrikkens vitalitet og forandringspotentiale, men skaber også nye litteraturvidenskabelige udfordringer. De handler ikke blot om at kortlægge det ekspanderende felt, samtidslyrikken udgør, men er også af mere principiel karakter. Eftersom det er et centralt kendetegn ved megen af nutidens toneangivende litteratur, at den ikke vil fikseres i forhold til kunstarter, medier eller genrer, men permuterer i et væld af nye arter og dukker op de mest overraskende steder, kan man nemlig ledes til at spørge, om genrebegrebet har udspillet sin rolle som litterært demarkationskriterium. Og i forlængelse heraf, om det stadig er relevant at bevare det gamle lyrikbegreb. Ja, er lyrik i det hele taget en definerbar genre, eller er det snarere et foranderligt felt med fleksible og flossede grænser? Og ikke mindst: Hvorfor er det vigtigt at beskæftige sig med disse spørgsmål; hvilken betydning spiller genren for tilegnelsen af et værk? Det er nogle af de problematikker, som denne artikel vil tage op.

\section{II}

Imidlertid er det at rejse spørgsmålet om genrer som at åbne et mere end to tusind år gammelt skab, hvorudfra skeletterne vælter. Spørgsmålet om klassificeringen af forskellige litterære former hører til litteraturvidenskabens grundproblemer, og siden Platon og Aristoteles er der givet et utal af bud på, hvordan man mest hensigtsmæssigt systematiserer genrer. Det, man med påberåbelse af de to antikke tænkere kalder for den klassiske inddeling af litteraturen i hovedgenrerne epik, lyrik og dramatik - men som Gérard Genette i "Introduction à l'architext" (1979) argumenterer for i virkeligheden kommer i stand via en række tvivlsomme forskydninger i fortolkningen af filosoffernes udsagn - har længe dannet en grundformel, som man i et sindrigt genresystem har kunnet specificere i underformer og underformers underformer. Dog har den status, som man har tildelt genrerne, varieret, og i genreteoriens nyere historie opereres der med en kontrast mellem henholdsvis en akron og en diakron tilgang; mellem på den ene side en essentialistisk, transhistorisk genreopfattelse og på den anden side en historisk funderet tilnærmelse, der afviser forestillingen om faste genrer.

Ser man mere specifikt på forholdet vedrørende lyrikken, kan dette formuleres som et spørgsmål om, hvorvidt der skal fastdefinerede træk til, for at noget kan bestemmes som lyrik, eller om lyrik tværtimod er en genre, hvis konstituerende elementer forandrer sig over tid. Og mens man nok i visse - særligt klassicistisk inspirerede - perioder har gjort en dyd ud af, at forfatternes tekster skulle leve op til foruddefinerede genreforventninger, har man fra romantikken og frem i højere grad vurderet en kunstners værdi på den grad af originalitet, hvormed han forvaltede sit kunstneriske talent og herunder tekstens genrepotentiale. Friedrich Schlegels angreb mod klassicismens regelæstetik og hans forsvar for en progressiv og genreblandende universalpoesi er velkendt, og modernismens historie fra midten af 1800-tallet og op igennem det 20. århundrede kan også på mange måder opfattes som brud med de etablerede former og herunder med traditionelle genrekonceptioner. Eksempelvis betegner opkomsten af det frie vers og af prosadigtet et opgør med den lyriske konvention om faste strofeformer, metrik og enderim, ligesom der inden 
for avantgarden sættes turbo på normbruddene i en gennemgående tværæstetisk bestræbelse, i et fors $\emptyset \mathrm{g}$ på at forene liv og værk samt i en revolte mod kunstinstitutionen selv. Som Tzvetan Todorov skriver i "L'origine des genres" (1978), er det ofte blevet opfattet "som et tegn på forfatterens autentiske modernitet, når han ikke vil adlyde adskillelsen af genrer" (Todorov 2009: 73).

Set i lyset af den moderne litteraturs historie synes der altså ikke at være tvivl om, at det er problematisk at ville opretholde en essentialistisk genreforståelse, og at der er behov for en mere historisk og pragmatisk tilgang til genrespørgsmålet. Imidlertid kan selve det forhold, at opfattelsen af litterære genrer til stadighed har forskudt og videreudviklet sig, også give anledning til endnu mere radikale genremæssige anfægtelser; anfægtelser, der ikke blot handler om at gå fra en akron til en diakron genreopfattelse, men om hvorvidt genrebegrebet har udspillet sin rolle. Som Larsen redegør for i sit introducerende genreafsnit i Drømme og dialoger, kan Benedetto Groce i Estetica (1902) og Maurice Blanchot i Le livre à venir (1959) ses som foregangsmænd for sådanne synspunkter, der siden bliver mere udbredte inden for forskellige poststrukturalistiske positioner. Det gælder bl.a. hos dekonstruktivisterne Jacques Derrida og Paul de Man, som begge afviser, at genrer kan udledes

på baggrund af strukturelle ligheder mellem tekster, og som i stedet opfatter genrer som afhængige af kontekst og læserindstillinger (Larsen 2009: 22ff.). Særligt radikalt udtrykkes det af Stanley Fish, der i "How to Recognize a Poem When You See One" (1980) argumenterer for, at den genrekonstituerende faktor er fortolkningsfællesskabet, det vil sige de mennesker, der beslutter sig for at ville læse noget som et digt og derfor fortolker en given tekst ud fra de konventioner, som hører til den poetiske læsning. Med Fishs egen spidsformulering: "Interpreters do not decode poems; they make them" (Fish 1980: 327).

Disse forbehold over for genrebegrebets relevans er af principiel karakter. Alligevel kan reservationen over for genrebegrebets anvendelighed synes at trænge sig mere på inden for nogle bestemte genrer end andre, og når det drejer sig om samtidslyrikken, der langt fra fremtræder som en veldefinerbar størrelse, og hvis tekster udvikler sig i et væld af nye former og i interaktion med forskellige medier, bliver det særligt præsent. For hvis lyrik ikke ser ud og opfører sig som det, vi normalt forstår ved lyrik, har vi da overhovedet brug for og udbytte af selve genrebetegnelsen? Gør det nogen forskel, om det, vi læser, hører eller på anden vis oplever, benævner sig selv som lyrik eller af os forstås som sådan?

III

Ja, det gør det faktisk; det er afgørende at fastholde genrebegreber, også når vi står over for eksperimenterende og grænseoverskridende litterære former. Det er mit korte svar, som jeg vil uddybe i det følgende. Eftersom det at insistere på genrebegrebets relevans naturligvis ikke er identisk med ikke at ville reformere, modificere og supplere tidligere genreforståelser, drejer et af de mere konkrete spørgsmål, som jeg vil tage op, sig om, hvordan man mest meningsfyldt arbejder med genreproblematikken i relation til samtidslyrik. Bl.a. kan man spørge, om det måske kræver, at vi skelner mellem lyrik og poesi, eller at vi varierer mellem brugen af begreberne 
genre og modus. Det vender jeg tilbage til. Først skal det mere overordnet handle om, hvilken funktion genren har i tilegnelsen af et værk, og her støtter jeg mig især til Alastair Fowlers Kinds of Literature. An Introduction to the Theory of Genres and Modes (1982).

At genrer ikke er overflødige konstruktioner og rene klassifikationsbegreber beregnet for dem, der skal finde ud af, hvor i biblioteket eller på forlagets hjemmeside en given bog skal placeres, men at de også spiller en aktiv rolle i vores tilgang til et værk, erfarer vi allerede, når vi tager en bog i hånden. Her står vi nemlig ikke bare med en bunke sider fyldt med bogstaver og ord. Vi står derimod med et værk; med en enhed af en slags, som vi uundgåeligt har visse forventninger til og udkaster bestemte forforståelser af for overhovedet at ville beskæftige os med, og i denne forbindelse er det oplagt, at genreforventningen er af stor betydning. Det er ikke for ingenting, at de fleste skønlitterære bøger skilter med deres genre på forsiden. Genreforholdet har en vigtig funktion i det litterære kredsløb fra forfattere over forlag til forhandlere og læsere. Et af de første spørgsmål, vi stiller til et værk, går således på, hvad det er for en slags, og tilsvarende er genren en af de mest grundlæggende kategorier, vi orienterer os ud fra, når vi begiver os ind i et værks univers.

Af egen erfaring kender vi til, at der er stor forskel på, om vi forventer at skulle læse eksempelvis en krimi, en eventyrbog eller en digtsamling; vi indstiller vores mentale perceptionsapparat forskelligt; læser ganske enkelt teksterne på forskellig vis, med blik for forskellige aspekter og med forventning om forskellige oplevelser. ${ }^{1}$ Og jo flere værker, vi har tygget os igennem, jo mere fintmasket et net kan vi have udviklet til ikke kun at tænke i storgenrerne epik, lyrik og dramatik samt diverse undergenrer, men også til at registrere genreblandinger, -udviklinger og nyopfindelser. Genrer er på én gang et basalt orienteringsredskab, som børn indlærer i skolens tidlige klassetrin, og et redskab, som optimeres gennem erfaring. "Tilegnelsen af generisk kompetence" er med Fowlers ord "en kompliceret og langvarig proces" (ibid. 55). Og en erfaren læser er der da også brug for, når det handler om at opfange de specifikke måder, hvorpå en given tekst forvalter genrespørgsmålet. Således er det kun den, der kender normen, som kan vide, hvornår den er brudt; kun den, der er hjemme i traditionen, som ved, hvornår der afviges fra den og gås ad nye veje.

Lige såvel som dette gælder for læseren, synes det at være et grundvilkår, at den litteratur, der intenderer at bryde decorum og skabe noget nyt, også er den, som er allermest afhængig af traditionen; at negationen og overskridelsen fordrer, eller i hvert fald kalder på, en bestemmelse og fastholdelse af en slags. Med Fowler: "the writer who cares most about originality has the keenest interest in genre. Only by knowing the beaten track, after all, can he be sure of leaving it" (Fowler 1985: 32). Tilsvarende skriver Todorov:

6 At værket ikke 'adlyder' sin genre, medfører ikke, at genren holder op med at eksistere; man kunne være fristet til at sige tværtimod. Og dét af en dobbelt grund. For det første, fordi overskridelsen for at eksistere som sådan behøver en lov - netop den, der skal overskrides. Man kunne gå længere: Normen kan kun ses - og leve - i kraft af overskridelser." (Todorov 2009: 75f.) 
I stedet for at tage den aktuelle situation med stor genrekompleksitet som en anledning til at kaste genrekortene på bordet og erklære dem for irrelevante, vil jeg ligeledes tale for at fastholde deres betydning. Det skyldes ikke alene det receptionsæstetiske vilkår, som jeg kommenterede tidligere, og som fremhæver genreforventningens afgørende rolle i mødet med værket, men også at et værks specifikke måde at forholde sig til spørgsmålet om genre og genreforventninger på er en central del af dets udsigelse. En vigtig pointe hos Fowler er, at genrer langt fra kun er virksomme som klassificeringsredskaber. Tværtimod er de primært fortolkningsmæssigt interessante, og den måde, som et værk gestalter sin genre på, har således stor betydning for vores opfattelse af værket.

Det bliver tydeligt, når man ser på de af samtidens lyriske praksisser, der er genremæssigt udfordrende. Betragter man f.eks. Lars Skinnebachs Enhver betydning er også en mislyd (2009), Pablo Llambías' trilogi Monte Lema (2011), Hundstein (2013) og Sex Rouge (2013), Christina Hagens White Girl (2012) samt Amalie Smiths I civil (2012), da er det nok værker, der alle af forlaget Gyldendal er rubriceret under digte, men som også samtidig repræsenterer et opbrud fra den lyriske genre. Og når det er væsentligt at mobilisere genrespørgsmålet i relation til disse værker, er det selvsagt ikke for at afgøre, om det reelt er lyrik, men derimod for at unders $\varnothing$ ge, hvilket mellemværende de hver især har med genren, hvordan de interagerer med den, og hvilken betydning dette har for værkets samlede holdning.

I forlængelse af Ludwig Wittgensteins begreb om familielighed forstået som "et kompliceret net af ligheder, som overlapper og krydser hinanden" (Fowler 2009: 47), afviser Fowler netop at se genrer som afgrænsede klasser. Han forstår derimod genrer som historisk foranderlige størrelser, der aktivt modelleres af de tekster, der deltager i dem (ibid. 20). En tilsvarende dynamisk tilgang til genrespørgsmålet findes hos Jean-Marie Schaeffer, der med begrebet genericitet understreger, at en tekst ikke så meget tilhører en genre, men fører en produktiv og transformerende dialog med den (Schaeffer 1997: 291). Endvidere kan man argumentere for, at det netop er det uventede og overraskende, der tiltrækker sig mest opmærksomhed, og at det i forlængelse heraf kun er logisk, at akkurat de værker, der bryder med vores genreforventninger, er dem, hvor genrespørgsmålet er mest presserende at diskutere. Ud fra et sådant perspektiv nivellerer genrebruddet ikke genrens betydning, men skaber snarere forøget sensibilitet for denne.

\section{IV}

Bevæger vi os nu videre ind på det specifikke område, der vedrører den lyriske genre, og erindrer vi denne artikels indledende udsagn om, at de fleste mennesker i vores kulturkreds har en forestilling om lyrik som en litterær kortform, der udtrykker et jegs oplevelser, tanker og følelser, er det præcis op imod denne forventning om det lyriske, at megen af den nye digtning fremtræder som genremæssigt eksperimenterende. Men hvordan kan det være, at denne lyriske norm har bjerget sig så forholdsvis intakt igennem? Hvorfor opleves genrebrud stadig så markant?

Et bud på et svar finder man hos Virginia Jackson, der i bl.a. Dickinson's Misery. A theory of lyric reading (2005), "Who reads poetry" (2008) og "Lyric" i The Princeton 
Encyclopedia of Poetry \& Poetics (2012) har argumenteret for, at der med romantikken indstiftes en sejlivet lyrisk norm, som siden har præget vores forståelse af, hvad poesi er. Jackson støtter hermed op om Genettes generelle beskrivelse af genrernes historie. Genettes pointe er, at forståelsen af hovedgenrerne lyrik, epik og dramatik som nærved naturgivne klasser er en romantisk konstruktion, der kun har lidt belæg i den faktiske historie. Jackson videreudvikler Genettes påpegning af, at vi i dag hænger fast i en snæver og vulgariseret forestilling om poesi, der ironisk nok forstår poesi som netop den type af lyrisk digtning, som Aristoteles udelod af sin poetik.

Mere præcist anfører hun, at mens poesi tidligere knap nok blev forstået som en genre, og i hvert fald ikke blev forstået ud fra snævre normer for det lyriske digt, så sker der fra det 18. århundrede et skift, hvor lyrik går fra at være et adjektiv til at blive et substantiv; fra at have været en kvalitet i poesi til at blive opfattet som en kategori og et æstetisk ideal, der synes at kunne inkludere næsten alle verseformer. Man identificerer ganske enkelt poesi med lyrik i betydningen tekstformer, som udtrykker personlige følelser i en koncentreret og harmonisk organiseret form, og som indirekte er adresseret til den private læser (Jackson 2012: 826). Dermed sker der imidlertid en indsnævring af det bredere poesibegreb, som med Jacksons ord er blevet lyrificeret. Og når denne lyrificeringsproces er slået så kraftigt igennem, skyldes det ikke mindst, at den er blevet styrket af at indgå i et fællesskab med litteraturkritikken og analysemetoderne i det 19. og 20. århundrede (Jackson 2005: 8). Jackson tilskriver her en afgørende betydning til nykritikken, som - mener hun - med baggrund i T.S. Eliot og I.A. Richards har skabt en model af alle digte som essentielt lyriske; en model, der i udgangspunktet var pædagogisk, men som udviklede sig til en læsepraksis og ligeledes influerede på de måder, som poesi blev skrevet på (Jackson 2012: 833).

Ifølge Jackson er det denne forståelse, der endnu udgør "the normative model for production and reception of most poetry" (ibid.). Det er identificeringen af poesi med lyrik, der fortsat konstituerer den norm, op imod hvilken vi opfatter mange af samtidens lyriske værker som genreeksperimenterende. Og det er også med baggrund i denne argumentation, at Stefan Kjerkegaard i artiklerne "Genreopbrud i 00'ernes danske poesi. Det selvbiografiske digt" (2010) og "Lyrik, medialisering, poesi" (2013) tilslutter sig Jacksons skelnen mellem poesi og lyrik og taler for en rehabilitering af det bredere poesibegreb, når man skal indfange samtidens poetiske praksisser (Kjerkegaard 2013: 24).

\section{V}

Har vi af Jackson fået et svar på, hvordan der kan være etableret en så stærk lyrisk norm, at vi stadig reagerer på værker, der afviger fra denne, synes der imidlertid at melde sig et andet spørgsmål. For hvordan kan det lade sig gøre, at den moderne lyriks historie på én gang kan beskrives som en tradition af opbrud (Todorov) og som historien om indstiftelsen af en mere snæver lyrisk norm (Jackson)? Står vi ikke her med uforlignelige synspunkter? Kun tilsyneladende, vil jeg mene, og for at forstå hvorfor, tror jeg, man må inddrage spørgsmålet om kanonisering. 
Samtidig med at bestræbelsen på at skabe stadigt nye og æstetisk tidssvarende udtryksformer går som en rød tråd igennem den moderne lyriks historie, har en lang række af de opbrud, man har set inden for lyrikken, nemlig stadigvæk kunnet rummes inden for de grundlæggende rammer for forståelsen af genren som en litterær kortform, der om ikke altid, så ofte er på vers, og som i hovedsagen kredser omkring et jegs erfaringer, følelser eller tanker. Det er i hvert fald tilfældet, når vi optegner den linje, der går fra romantikken over symbolismen til modernismens forskellige faser. Og i relation til de poetiske praksisser, hvor det ikke har kunnet lade sig gøre - her tænker jeg især på mere radikale avantgardistiske former - da har disse længe haft en mere perifer position. Det betyder selvsagt ikke, at man ikke har bemærket og anerkendt avantgardens genremæssigt eksperimenterende former, men nok at de ikke er blevet kanoniseret og institutionaliseret i samme grad som den lyrik, der har haft et mere klassisk formsprog, og som har holdt sig inden for bogsidens udstukne format.

Imidlertid synes der nu at være ved at blive vendt om på styrkeforholdet mellem de mere klassisk modern(istisk)e og de avantgardistiske lyriske praksisser. Avantgarden banker ikke blot på døren til det etablerede selskab, men nærmest sparker den ind. Det gælder som tidligere nævnt ikke kun i forhold til den fremadstormende interaktionslyrik, men også når man ser på de mange måder, hvorpå lyrikken går på tværs af kunstarter og medier; hvorpå den skruer op for sine materielle og performative sider. Disse aktuelle lyriske former kan ses i forlængelse af avantgardens tidligere manifestationer og dens gennemgående eksperimenterende og tværgående drive. ${ }^{2}$ Lyrikkens aktuelle tendens til at gå på tværs af medier, nedbryde grænser mellem kunstarter og opsøge alternative udfoldelsesmuligheder har således tråde tilbage til begyndelsen af det 20. århundrede, hvor den historiske avantgarde etablerede sig med underformer som ekspressionisme, dadaisme, surrealisme og futurisme, ligesom avantgarden med skiftende styrke præger forestillingerne om kunsten op igennem århundredet.

I en dansk sammenhæng finder der især en revitalisering og genoptagelse af avantgardetraditionen sted fra de sene tressere. På dette tidspunkt udfoldes der en stor eksperimenterende virkelyst, som bl.a. giver sig udslag i en leg med bogens materialitet, i Jazz'n'Poetry og performancekunst samt i nedbrydningen af grænserne mellem populær- og finkultur. Der er med andre ord en gruppe forfattere og kunstnere som f.eks. Jørgen Leth, Hans-Jørgen Nielsen, Dan Turèll, Per Kirkeby, Henrik Have og Peter Laugesen, der såvel inden for bogmediet som på tværs af kunstarterne bryder med de etablerede kunstneriske udtryksformer og normer. Og de selvsamme forfattere ser man da netop også rekanoniseret i forbindelse med den øgede interesse for litteraturens åbne felt, som opstår omkring år 2000. Her bliver eksperimenterende litteratur, der tidligere har haft undergrundsstatus, mere etableret og komplementeres desuden af udenlandske inspirationskilder, især fra USA. Samtidig træder der en række nye markante forfatterstemmer frem, som på baggrund af deres specifikke ståsted i historien arbejder videre inden for det, som jeg med reference til den amerikanske kunstkritiker Rosalind Krauss' begreb om the expanded field har kaldt "det stadigt udvidende felt" (Mønster 2013). 
Med henvisning til denne litteraturhistoriske udviklingslinje kan man naturligvis fremføre, at der ikke er noget hverken fundamentalt nyt eller principielt overraskende på færde, hvad angår den udvidelse, overskridelse og problematisering af de litterære genrer og herunder af lyrik, som vi er vidne til i disse år. Det har længe været avantgardens praksis. Men selvom tendensen ikke i sig selv er ny, så er det omfang, den opfindsomhed, variation og originalitet, hvormed disse eksperimenter finder sted, bemærkelsesværdig. Det er påfaldende, hvor mange interessante værker, der produceres i disse år, som går op imod vores hævdvundne opfattelse af, hvad lyrik er. Genreeksperimenterne sætter sig igennem i et omfang og med en kraft, der måske endnu mere nu end nogensinde før påkalder sig opmærksomhed, og som under alle omstændigheder kun svært lader sig ignorere.

\section{VI}

Det fører os videre til at overveje, om der er nogle mere overordnede forhold i samtiden, som kan have medvirket til at sætte den hævdvundne opfattelse af lyrik under pres og styrke fremkomsten af alternative former. Uden illusioner om at kunne give en udtømmende forklaring vil jeg pege på fire forhold, som jeg tror, er vigtige brikker til forståelsen heraf, nemlig medialisering, litterær kultur, publikationsformer og øget politisering.

Hvad medialieringen angår, befinder vi os for første gang siden bogtrykkerkunstens udbredelse i en situation, hvor bogmediets overherredømme reelt er udfordret. De digitale medier gennemsyrer vores virkelighed, og selvom bogen stadig er et privilegeret litterært medium, er den ikke længere enerådende. Lyrikken udfolder sig også via internettet, den skrives på blogs, har sms'ens form og kan opleves på IPad. Og i relation til genrens indtagelse af disse nye medier er der ikke kun tale om, at gammelkendte former transporteres ud på nye platforme; mediernes virkemåde influerer den lyriske genre og giver nye æstetiske muligheder. Det fremgår tydeligt, når man sammenligner lyriske værker, der er udkommet i bogform og remedieret som netpoesi. I værker som Morten Søndergaards Landskaber omkring digtet Kompas (2001), der relaterer til digtet "Kompas" fra Bier dør sovende (1998); Christian Yde Frostholms Afrevne ord, der i 2004 kom i såvel en bog- som netudgave, og Cia Rinnes archive zaroum (2008), der er en remediering af digtsamlingen zaroum fra 2001, ses det, at netpoesien ofte er genremæssigt mere kompleks, idet den skaber en fleksibel tekst, der kan kombineres med billede og lyd, ligesom den arbejder med en mere åben værkform og med en øget inddragelse af læseren i tilegnelsen af værket. Med Hans K. Rustads ord sker der i den digitale poesi det, at værket forskydes fra at være et stabilt objekt til at blive en sanselig hændelse (Rustad 2012: 78).

Samtidig med at en del lyriske værker har opsøgt og undersøgt de nye muligheder, som de elektroniske medier giver, har man imidlertid også set, at medialiseringen har kastet fornyet opmærksomhed tilbage på bogmediet selv. Der er kommet en øget bevidsthed om de forskellige mediers medialitet, som har inkluderet bogen, og i stedet for at fremstå som et gennemsigtigt medium, hvor teksten alene er betydningsbærende, inddrages bogens materielle side i stadigt højere grad i betydningsproduktionen. Det gælder lige fra værker, der som Mette Moestrups $D \emptyset L \emptyset G N D \emptyset$ 
(2012) og Gerd Laugesens Har du set min kjole (2011) bevidst spiller på deres valg af papirkvalitet og -farve til kunstnerbøger og bogobjekter, der som Martin Larsens Svanesøsonetterne (2004) og Morten Søndergaards Ordapotek (2010) er defineret ved, at værkets ide og indhold ikke kan adskilles fra dets udformning og herunder fra det materiale, det er trykt på. I bogobjektets form har lyrikken således entreret det udstillingsrum, der ellers primært var reserveret billedkunst og skulptur. Med reference til Hans Ulrich Gumbrecht skriver Krista S. G. Rasmussen, at der er fremkommet en nymateriel bølge, som vidner om, at der som reaktion mod det digitales flygtighed opstår en længsel efter det analoge og de fysiske objekter (Rasmussen 2013: 44).

Herfra kan vi gå videre til det andet punkt, der har med en ændring i den litterære kultur at gøre. Mens produktion og konsumption af lyriske værker længe har været aktiviteter, som foregik stillesiddende og i hver sit aflukke, har litteraturen nu i højere grad entreret et socialt, mellemmenneskeligt felt. Vi befinder os i en oplevelses- og eventkultur, og igennem de seneste år har der været en markant stigning i antallet af steder, som lægger rum til fremførelse og formidling af lyrik. Litterære cafeer, scener og festivaller er kommet til at spille en vital rolle for mødet mellem forfattere og deres publikum. Parallelt med disse steders tiltagende betydning har man set en $\varnothing$ get udforskning og anvendelse af de muligheder, som livearrangementerne giver. Den klassiske digtoplæsning er om ikke blevet afløst af, så i hvert fald komplementeret af diverse former for digtperformance, hvor der ikke blot formidles et allerede eksisterende værk, men hvor realiseringen udgør et værk i sig selv. Især har der været en markant forøgelse i antallet af lyrikere, som har begivet sig ind på området mellem lyd og lyrik. Lyrikkens orale dimension er blevet boostet på mange forskellige måder, der går fra spoken word og poetry slam over det rappede til det poppede og videre mod det rockede og syrede, hvilket Peter Dyreborg, Mouritz/ Hørslev Projektet, Schweppenhäuser/Thomsen og Morten Søndergaard, Klimakrisen, Skammens vogn og Stemmejernet er gode eksempler på. Blandt de yngre digtere synes det mere at være reglen end undtagelsen, at de indtænker deres værker i flere forskellige performative og kunstneriske kontekster.

Denne forskydning i retning af oplevelsesprægede lyriske sammenhænge bevirker - som allerede antydet - et skift i forfatter- og læserrollen, der bliver mere dynamisk. Den samtidige tilstedeværelse giver mulighed for umiddelbar respons og varierende grader af interaktion. Endvidere er etableringen af et fælles felt ikke begrænset til livearrangementet. Det eksisterer også på nettet, der fungerer som et sted for dokumentation, diskussion og reklame, og som for dem, der ikke var til stede ved et givent arrangement, skaber mulighed for at opleve i hvert fald noget af det, man gik glip af. Foruden forfatteres egne blogs er YouTube en ofte anvendt kanal, ligesom danske sites som Bogtube, Forfatterstemmer og Fieldsarkivet tilbyder oplæsninger, lyrikperformance, videodigte mv. Ja, selv bibliotekerne har måttet nytænke deres måde at fungere på, så de bedre har kunnet rumme litteraturens nye former. ${ }^{3}$

Som et tredje punkt i rækken af aspekter, der har influeret afgørende på det opbrud, vi har set inden for den lyriske genre, står ændrede forhold vedrørende publicering. En kompleks cocktail af økonomisk lavkonjunktur og nye publicerings- 
kanaler har skabt en situation, hvor der i Danmark reelt kun er ét stort kommercielt forlag tilbage, der huser lyrikken, nemlig Gyldendal, og hvor de øvrige aktører udgøres af en underskov af mere eller mindre veletablerede small press-foretagender. Det er foretagender, der for nogles vedkommende har en lang, men ofte lidt omtumlet historie, mens andre har karakter af mere kortvarigt åbne kanaler. Hvad der i udgangspunktet har været affødt af krise, synes altså, når vi ser på tilvæksten af small press, at være blevet vendt til en fordel - $\mathrm{i}$ hvert fald for den mere eksperimenterende litteratur og herunder lyrikken. Uden at være styret af intentioner om at tjene mange penge og slå an hos et bredt publikum har disse foretagender skabt en niche for lyrikken, hvor den har haft gode betingelser for at udfolde sig i nye retninger. Dertil kommer, at der er opstået forskellige elektroniske publikationskanaler, som har gjort det både billigere og langt mindre kompliceret at udgive digte. Det gælder netog smsforlag, elektroniske tidsskrifter og digtsites, ligesom en del lyrikere publicerer på sociale medier og egne blogs. Og som nævnt i forbindelse med punktet vedrørende medialisering har indtagelsen af disse platforme også medvirket til forøgelsen af lyrikkens diversitet.

Hermed er vi kommet til det fjerde og sidste træk, jeg vil fremhæve, og som jeg med en vis tøven kalder politisering. Denne politisering stikker allerede sit hoved frem, når vi taler om forskellen vedrørende store og små forlag, men det, jeg primært sigter til her, er, at der uanset hvilke udgivelseskanaler, vi befinder os indenfor, synes at være en tendens til, at lyrikken i det nye årtusinde i højere grad end i 1980'erne og 1990'erne går i clinch med aktelle problematikker vedr. f.eks. klima, kapitalisme, forbrugerisme, magtforhold, race, hudfarve og køn. I stedet for en primært æstetisk og eksistentielt orienteret lyrik, der kredser om det skrivende subjekt selv, har vi på den anden side af årtusindskiftet fået en lyrik, der i stigende grad er verdensvendt og subversiv, og som i overensstemmelse hermed har en mere heteronom, diskursiv og uren karakter. Opgøret med de gældende normer og foruddefinerede systemer er nemlig ikke alene indholdsmæssigt bestemt; det ledsages af et behov for et ændret udtryk, og således kendetegner det samtidslyrikken, at den opgiver idealet om autonomi og heller ikke på det form- og genremæssige plan synes at ville lægge sig for pænt og velordnet tilrette.

Med påpegningen af disse forhold vedrørende medialisering, litterær kultur, publikationsformer og øget politisering gør jeg mig som nævnt ingen illusion om at have givet en udtømmende forklaring på, hvorfor der netop nu synes at være skabt grobund for et paradigmeskift i opfattelsen af den lyriske genre. Men jeg tror, at det er nogle af de forhold, som har medvirket afgørende hertil, og som ved at indgå i konstellation med hinanden har gjort, at den aktuelle situation reelt skiller sig ud fra tidligere tidspunkter. Nok kan man sige, at mange af de ting, vi oplever i lyrikken i dag, ikke er principielt nye, for så vidt som de har rødder tilbage i litteraturhistorien og her især, men ikke udelukkende, forbinder sig med avantgardens forskellige former. Men ikke desto mindre gør de særlige vilkår og de specifikke teknologiske muligheder, som kendetegner nutiden, at opbruddet inden for genren også udfolder sig anderledes og med en anden gennemslagskraft end tidligere. At noget ikke er principielt nyt, betyder ikke, at det ikke er nyt. 


\section{VII}

Det sidste trin i denne artikels diskussion af samtidslyrikken og genrespørgsmålet består i at konkretisere de måder, som samtidslyrikken intervenerer med genren. Det vil sige at give specifikke eksempler på de måder, hvorpå de nye fremadstormende former går i clinch med den gængse opfattelse af lyrik samt diskutere, hvilke konsekvenser det har for vores måde at arbejde med genrebegrebet på.

Vi har allerede været inde på, at samtidslyrikken i stigende grad har forbundet sig med andre kunstarter; at den har nærmet sig sine søsterkunstarter og ikke alene på den skrevne teksts betingelser arbejder med musiske og billedlige elementer, men også helt konkret har taget skridtet ind på billedkunstens og musikkens område. For ikke at sige at den er begyndt at orientere sig mere mod performance; mod den måde den gør sig på i stedet for, hvordan den er. Denne udvidelse af lyrikkens virkefelt betyder imidlertid også, at vi i vores tilegnelse må navigere i et bredere interartielt felt og vurdere lyrikken ud fra andre standarder end rent tekstuelle. Således kræves det, at vi medtænker parametre som materialitet, kropslighed, gestik, stemme, tone og en lang række andre faktorer, der overskrider skriftens rammer.

Men også når det gælder den lyrik, der har teksten som sit primære aftryk, ser man forskellige måder, hvorpå der gøres op med den centrallyriske forståelse og lægges op til diskussion af genrespørgsmålet. En af disse måder har form af remiks, sampling og genbrug af genrematricer og konkrete litterære tekster. Værker som Simon Grotrian: Risperdalsonetterne (2000), Peter Adolphsen og Ejler Nyhavn: Katalognien (2009) og Rasmus Nikolajsen: Socialdemokratisk digt (2010) er kendetegnet ved, at de udforsker klassiske digtgenrer eller sætter velkendte tekster ind i nye og overraskende sammenhænge. Tilsvarende gælder det for f.eks. Olga Ravn: Jeg æder mig selv som lyng (2012) og Christina Hagen: White Girl (2012), at værkerne tager afsæt i specifikke tekstuelle forlæg. Montageformer, readymades, konceptuel og postproduktiv litteratur er i det hele taget in, hvilket bevidnes af forfattere som f.eks. Martin Larsen (Monogrammer (2007)), Christian Yde Frostholm (Afrevne ord (2004)), Martin Glaz Serup (Ja, jeg smager månedens kunstnervin! (2010)) og Chresten Forsom (Manhattan (2011)).

Samtidig med at en del værker lægger afstand til den klassiske centrallyriske forestilling om poesien som højborgen for et jegs oplevelser og refleksioner, er der imidlertid også en modsat tendens i form af værker, som trækker så voldsomt på hovedstolen, at de destabiliserer den hævdvundne skelnen mellem forfatter og lyrisk jeg, mellem fakta og fiktion. Foruden i den allerede nævnte trilogi af Pablo Llambías melder denne biografiske problematik sig i bl.a. Maja Lee Langvad: Find Holger Danske (2006), Eva Tind Kristensen: eva +adolf, (2011), Asta Olivia Nordenhof: Det nemme og det ensomme (2013), Julie Sten-Knudsen: Atlanterhavet vokser (2013) og Yahya Hassan: Yahya Hassan (2013). Mens den autonome læsning var i høj kurs inden for nykritikken og dekonstruktionen, står vi i dag ofte over for lyriske værker, hvor det ikke giver mening at insistere på værkets selvberoende karakter, og hvor spillet mellem virkelighed og fiktion udgør en central pointe. Det gælder også, når samtidslyrikken engagerer sig i centrale politiske og værdimæssige problemstillinger og behandler emner som klimakrise, velfærdssamfund, forbrugerisme og ligestilling både globalt, økonomisk og kønspolitisk. Ursula Andkjær Olsen, Mette 
Moestrup, Lars Skinnebach, Theis Ørntoft og Nikolaj Zeuthen er blandt de forfattere, der kan nævnes her.

Som en sidste markant måde, hvorpå samtidslyrikken lægger op til diskussion med genren, står de forholdsvis mange værker, der opfinder nye poetiske værkformer og særegne genrer. Foruden nogle af de førnævnte titler kan det eksemplificeres af Mikkel Thykiers .katalog. (2001), Lars Skinnebachs Post it (2009), Amalie Smiths I Civil (2012); ligesom Gerd Laugesens Har du set min kjole? (2011) og Lommetørklædesamlinger (2012) samt Morten Søndergaards Ordapotek (2010) er repræsentanter for nye genreblandende og tværmediale lyriske former. Det er karakteristisk for mange aktuelle udgivelser, at de insisterer på at være lyriske på deres egen specifikke vis, og derfor oplever man ikke kun en stor diversitet i forhold til, hvordan værkerne ser ud, men også i de måder, som de forholder sig til det at være digte, lyrik og poesi. Og for at vende tilbage til et af de spørgsmål, jeg rejste tidligere, synes det da også i forhold til nogle af disse værker at være oplagt at skelne mellem genre og modus, idet der er nogle værker, hvor det unægtelig er mere dækkende at sige, at de er lyriske, end at der er tale om lyrik - med den mulighed for en mere åben og mindre kategorial bestemmelse, som trods alt ligger i den adjektiviske betegnelse.

\section{VIII}

Når man tager det vide virkefelt i betragtning, som samtidslyrikken indgår i, er det klart, at det ikke giver mening at fastholde en entydig definition af, hvad lyrik er. Mere relevant synes det at være at se lyrikken som et dynamisk og stadigt ekspanderende felt, der interagerer med andre genrer og kunstarter, og som har vist sig særdeles fleksibelt og omstillingsparat. Vi befinder os tydeligvis et sted i litteraturog kulturhistorien, hvor der opleves et behov for at åbne sluserne og brede sig ud. Måske kommer der senere et tidspunkt, hvor lyrikken igen vil forsøge at samle sig og optegne klarere grænser omkring sit virkefelt. På samme måde i øvrigt, som også den danske firserlyrik reagerede mod, hvad de oplevede som 1970'ernes udvanding af poesien.

Imidlertid er det, at man ikke kan eller vil give en fast definition af genren, ikke det samme som at fornægte, at genrebevidstheden er der, og at den spiller en central rolle på de forskellige niveauer i det litterære kredsløb. Hvilke træk i en tekst, der er definerende for dens tilhørsforhold til lyrikken kan variere; alligevel er der en vis fællesmængde, hvorfra disse træk hentes, og som har at gøre med bl.a. korthed, typografisk opstilling i strofer og vers, betydningstæthed, særsprog, udtryk frem for beretning, lyrisk jeg, visualitet og musikalitet. Med Fowlers videreudvikling af Wittgensteins familielighedsbegreb gives der plads til en sådan dynamisk genretilgang, som kan rumme lyrikkens mangfoldige former og dens flersidige interaktioner. Og selvom genrebegrebet langt fra er den eneste måde, hvorpå man kan markere slægtskaber imellem tekster, er det dog en af de mest fundamentale måder at foretage sådanne grupperinger på og dét selvsagt ikke for grupperingernes egen skyld, men for bedre at kunne forstå de enkelte værker og de dialoger, de lægger op til. ${ }^{5}$ 


\section{Noter}

I Fowler siger tilsvarende: "Genrer har en funktion i den litterære kommunikation: De former aktivt oplevelsen af det litterære værk. Opfatter man The Jew of Malta som en grusom farce, vil man reagere anderledes på skuespillet, end hvis man opfatter det som en tragedie" (Fowler 2009: 41).

2 I introduktionen til 21st-Century Modernism. The 'new' poetics (2002) skriver Marjorie Perloff tilsvarende: "Far from being irrelevant and obsolete, the aesthetic of early modernism has provided the seeds of the materialist poetic which is increasingly our own - a poetic that seems much more attuned to the ready-mades, the 'delays' in glass and verbal enigmas of Marcel Duchamp, to the non-generic, non-representational texts of Gertrude Stein, and to the sound and visual poems, the poem-manifestos and artist's book of Velimir Khlebnikov than to the authenticity model - the 'true voice of feeling' or 'natural speech' paradigm" (Perloff 2002: 3f).

3 Et godt eksempel er Åby Bibliotek, hvor man har etableret et særligt litteratursted til formidling af alternative litterære former jf. https://www.aakb.dk/facilitet/litteraturstedet.

4 Se "Samtidslyrikkens tværmediale liv. Et rids over en genre i forandring" (2012) for en uddybning af forholdene vedrørende small press og alternativ publicering.

5 Denne artikel er blevet til ifm. forskningsprojektet Contemporary Poetry between Genres, Art Forms, and Media, der er støttet af Det Frie Forskningsråd. Kultur og Kommunikation.

\section{Litteratur}

Fish, Stanley (1980): "How to Recognize a Poem When You See One" i Is There a Text in This Class?, Cambridge: Harvard University Press.

Fowler, Alastair (2009): "Genrebegreber" i J. D. Johansen og M. L. Klujeff (red.): Genre. Aarhus: Aarhus Universitetsforlag.

Genette, Gérard (1997): “Introduktion til arketexten” i E. H. Aurelius og T. Götselius (red.): Genreteori, Lund: Studentlitteratur.

Jackson, Virginia (2005): Dickinson's Misery. A theory of lyric reading, Princeton / Oxford: Princeton University Press.

Jackson, Virginia (2008): "Who reads poetry" i PMLA vol. 123, no. 2.

Jackson, Virginia (2012): "Lyric" i R. Greene (red.): The Princeton Encyclopedia of Poetry \& Poetics, Fourth Edition.

Johansen, Jørgen Dines og Marie Lund Klujeff (2009): Genre, Aarhus: Aarhus Universitetsforlag. Kjerkegaard, Stefan (2009): "Genreopbrud i 00'ernes danske poesi. Det selvbiografiske digt”, Passage 63.

Kjerkegaard, Stefan (2013): "Lyrik, medialisering, poesi" i Diktet utenfor diktsamlingen. Modernisme i nordisk lyrikk 6, Bergen: Alvheim \& Eide. Akademisk forlag.

Larsen, Peter Stein (2009): Drømme og dialoger. To poetiske traditioner omkring 2000, Odense: Syddansk Universitetsforlag.

Mønster, Louise (2012): “Samtidslyrikkens tværmediale liv. Et rids over en genre i forandring”, Kritik 203.

Mønster, Louise (2013): "Samtidslitteraturens udvidede felt". Artiklen kan findes på http://www. litteratursiden.dk/artikler/samtids-litteraturens-udvidede-felt.

Perloff, Marjorie (2002): 21st-Century Modernism. The 'new' poetics. Massachusetts: Blackwell Publishers.

Rasmussen, Krista S. G. (2013): "Når lyrikken tager form. Boghistorie og nymaterialitet" i Passage 69. 
Rustad, Hans Kristian (2012): Digital litteratur, Oslo: Cappelen Damm Akademisk.

Schaeffer, Jean-Marie (1997): "Från text till genre. Anteckningar om genreproblematiken" i E.H. Aurelius og T. Götselius (red.): Genreteori, Lund: Studentlitteratur.

Todorov, Tzvetan (2009): "Genrernes oprindelse" i J. D. Johansen og M. L Klujeff (red.): Genre, Aarhus: Aarhus Universitetsforlag. 